\title{
Leucocyte migration inhibition test in coeliac disease - a reappraisal
}

F G SIMPSON, H P FIELD, P D HOWDLE,

D A F ROBERTSON, AND M S LOSOWSKY

From the Department of Medicine, St James's University Hospital, Leeds

SUMMARY Results of the direct leucocyte migration inhibition (LMI) test using gluten fraction III as antigen were unaffected by incorporation of puromycin into the culture medium at concentrations shown to prevent lymphokine mediated inhibition. Results of the LMI test performed with purified polymorphs were similar to and correlated with results of the standard LMI test using mixed leucocytes in both coeliacs and controls. The addition of purified $\mathrm{T}$ lymphocytes did not increase migration inhibition. Normal leucocytes incubated with serum from coeliac patients and washed showed marked migration inhibition when incubated with gluten fraction III. This sensitisation of normal leucocytes was prevented by preincubation with aggregated human IgG. These results suggest that leucocyte migration inhibition by gluten in coeliac disease is not due to lymphokine production by sensitised lymphocytes but is caused by cytophilic antibody.

There is considerable evidence for abnormal immunity to gluten in patients with coeliac disease ${ }^{1}$ and it is suggested that this may be important in pathogenesis. In recent years attention has been focused on the role of cell mediated immunity to gluten and much of the evidence supporting the existence of such immunity comes from use of the leucocyte migration inhibition (LMI) test. ${ }^{2-5}$ In its simplest form this test involves incubation of peripheral blood leucocytes with the putative antigen and comparison of the migration of these leucocytes with those cultured in control medium. Inhibition of migration in the presence of antigen is taken to represent production of lymphokines by $T$ lymphocytes specifically reactive to the antigen and thus to provide a measure of cell mediated immunity. In general the correlation between results of the LMI test and delayed hypersensitivity shown by skin testing has been good for antigens such as purified protein derivative where the importance of cellular immunity is clear. ${ }^{6-8}$ Inhibition of leucocyte or macrophage migration, however, may be produced by factors elaborated by B lymphocytes 9 and other cell types ${ }^{10}$ by cytophilic antibody,,${ }^{11-16}$ by immune complexes ${ }^{17} 18$ and by direct toxicity of the

Received for publication 22 July 1982 putative antigen. ${ }^{19}$ Furthermore, skin tests with gluten subfractions have shown no evidence of delayed hypersensitivity to gluten in coeliac disease. ${ }^{1}$ We have therefore further investigated the LMI test in coeliac disease using puromycin as an inhibitor of lymphokine production and using purified white cell populations to determine whether or not the assumption that results of the LMI test correlate with T-lymphocyte mediated immunity to gluten is justified. We have also investigated the possibility that a serum factor such as cytophilic antibody is involved by attempting to sensitise normal leucocytes to gluten by preincubation with sera from coeliac patients.

\section{Methods}

\section{PATIENTS}

Ten patients (seven women and three men) with coeliac disease were studied. All had typical jejunal biopsy changes at the time of diagnosis and all showed histological improvement on gluten exclusion. Mean age was 25 years (range 12-53 years). Five patients were studied while taking a normal diet and the other five had been on a gluten free diet for at least six months (mean 11 months). The eight healthy controls (mean age 30 years) were hospital personnel. 


\section{ANTIGENS}

Gluten fraction III was prepared according to the method of Frazer et $a l^{20}$ and was used at a final concentration of $1 \mathrm{mg} / \mathrm{ml}$ in the LMI test. As a positive control purified protein derivative was used. Five normal controls were Mantoux-tested with 1 IU of purified protein derivative intradermally. The diameter of induration produced was measured at 24 hours. Induration of greater than $10 \mathrm{~mm}$ diameter was taken as a positive response. Cells from the five controls were used in LMI tests with preservative free purified protein derivative (Ministry of Agriculture, Weybridge, Surrey) at a final concentration of $200 \mu \mathrm{g} / \mathrm{ml}$.

\section{LEUCOCYTE SEPARATION}

Leucocytes were prepared from defibrinated venous blood for the LMI test by dextran sedimentation for 30 minutes as previously described. ${ }^{3}$ Differential white cell counts on leucocytes prepared in this fashion showed a mean of $63 \%$ polymorphs, $33 \%$ lymphocytes, and $4 \%$ eosinophils and monocytes.

\section{SEPARATION OF LEUCOCYTE SUBPOPULATIONS}

Mononuclear cells were separated from heparinised venous blood by centrifugation at $400 \mathrm{~g}$ for 30 minutes through Histopaque 1077 (Sigma Chemicals). Mean yield of mononuclear cells from $30 \mathrm{ml}$ of blood was $3 \cdot 2 \times 10^{7}$ cells. Differential counts showed more than $95 \%$ lymphocytes with the remainder monocytes. The red cell pellets from beneath the Histopaque were combined and allowed to sediment for 20 minutes at $37^{\circ} \mathrm{C}$ and the polymorph-rich supernate removed. Mean yield of polymorphs was $3 \cdot 14 \times 10^{7}$ cells. Leishman stained smears of these preparations showed more than 99\% polymorphs with occasional eosinophils and no mononuclear cells. Aliquots of the mononuclear cell preparations were taken for use in the LMI test and the remainder used for separation into $\mathrm{T}$ and $\mathrm{B}$ cells. This was achieved by rosetting with neuraminidase treated sheep red blood cells (n-SRBC). Two millilitres of $2 \%$ n-SRBC were mixed with the mononuclear cells and spun at $1000 \mathrm{rpm}$ for five minutes. After one hour at room temperature the cell pellet was gently resuspended and $1.15 \mathrm{ml}$ Histopaque introduced carefully under the cells with a Pasteur pipette. After centrifugation at $1800 \mathrm{rpm}$ for 20 minutes the rosetted $\mathrm{T}$ cells were pelleted under the Histopaque and the non-rosetted cells at the medium-Histopaque interface. The SRBC were removed from the $\mathrm{T}$ cells with $0.8 \%$ ammonium chloride. All cell preparations were washed twice in medium before use in the LMI test. Cell viabilities were always over $90 \%$ as judged by trypan blue exclusion. ${ }^{21}$ The effectiveness of the T-B separation was checked periodically by re-rosetting using nSRBC for T cells and with chromic chloride treated fresh ox erythrocytes conjugated with antihuman immunoglobulin for B cells. ${ }^{22}$ The $T$ cell enriched preparation always contained more than $92 \% \mathrm{~T}$ cells and less than 5\% B cells and the B cell enriched preparation more than $54 \%$ B cells (usually more than $70 \%$ ) with less than $10 \% \mathrm{~T}$ cells. Mean recovery of cells from the rosetting procedure was $76 \%$.

\section{L.MI TEST}

This was performed by a capillary tube method as previously described. ${ }^{3}$ The areas of leucocyte migration were measured at 20 hours by planimetry of traced projected images of the cultures and migration index calculated as:

Migration index $=$

Mean area of migration in the presence of antigen

Mean area of migration in control medium

When using mixtures of polymorphs and lymphocytes these were mixed in the proportion $2: 1$ to reproduce the approximate proportions of cells in the dextran sedimented leucocytes used in the standard test. The effect of puromycin at a final concentration of $15 \mu \mathrm{g} / \mathrm{ml}$ on leucocyte migration in the presence and absence of antigen was tested on six coeliacs and six controls with gluten fraction III as antigen and five controls with purified protein derivative as antigen.

\section{SERUM INCUBATION}

To investigate whether a serum factor might be involved in sensitising leucocytes to gluten the LMI test was performed with cells obtained by dextran sedimentation from a normal control which were incubated at $37^{\circ} \mathrm{C}$ for one hour with sera from six of the coeliac patients at a dilution of one half. The cells were then washed twice in cold medium and used in the LMI test as usual. Aliquots of the cells were also preincubated with aggregated human $\operatorname{IgG}$ to attempt to block $F_{c}$ receptors. The $\operatorname{IgG}$ (at 64 $\mathrm{mg} / \mathrm{ml}$ ) was aggregated by heating to $63^{\circ} \mathrm{C}$ for 20 minutes and incubated with the cells for one hour at $37^{\circ} \mathrm{C}$ at a final concentration of $5.8 \mathrm{mg} / \mathrm{ml}$. The cells were then washed twice in cold medium and incubated with coeliac serum as above, rewashed twice and used in the LMI test.

\section{Results}

The effect of puromycin at $15 \mu \mathrm{g} / \mathrm{ml}$ on migration indices with gluten fraction III as antigen is shown in Fig. 1. With puromycin there is no trend towards increasing migration indices to approach unity as 


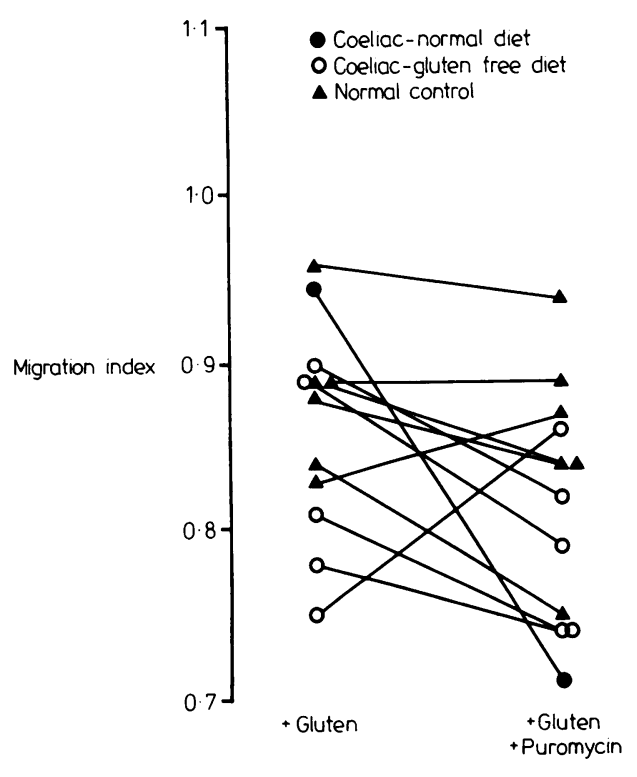

Fig. 1 Effect of puromycin on migration indices with gluten fraction III as antigen in normal controls and coeliac patients.

would be expected if a lymphokine were involved. This contrasts with the effect of puromycin on migration index with purified protein derivative as antigen (Fig. 2). With purified protein derivative alone the three Mantoux-positive subjects all showed migration inhibition which in each case was reduced by puromycin. Puromycin did not affect migration indices of the Mantoux-negative subjects. Absolute migration areas of cultures performed with puromycin alone (without antigen) did not differ significantly from those in culture medium without additives.

Figure 3 illustrates the comparison of migration indices using gluten fraction III in the standard LMI test and in the LMI test performed with polymorphs alone, mononuclear cells alone, and with polymorphs with added $\mathrm{T}$ cells and with added $\mathrm{B}$ cells. (On some occasions the yield of mononuclear cells or B cells was insufficient to allow the setting up of quadruplicate cultures and the numbers in these experiments are thus reduced.) With the standard LMI test the coeliac patients show a significant reduction of migration index compared with controls $(p<0.05$ by Wilcoxon's rank sum test). A similar difference is observed in the test performed with purified polymorphs. Mononuclear cells alone were not inhibited either in coeliacs or controls. When the test was performed with polymorphs with

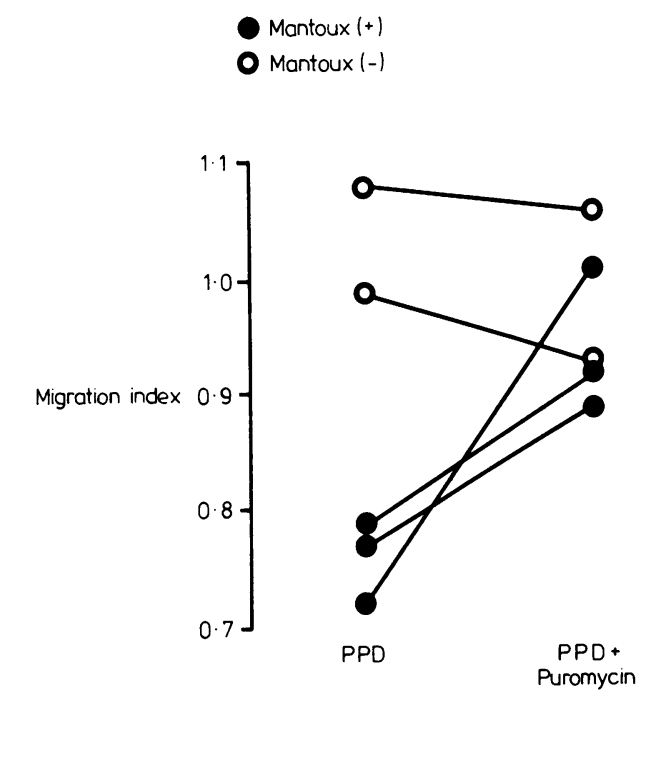

Fig. 2 Effect of puromycin on migration indices with purified protein derivative as antigen.

added $\mathrm{T}$ cells or with added $\mathrm{B}$ cells results were similar to those with polymorphs alone, although the difference between coeliacs and controls fails to reach statistical significance in each case. There were no significant differences between results from treated and untreated coeliacs in these experiments in contrast with previous findings: this probably reflects the small numbers studied.

Figure 4 shows the correlation between individual migration indices to gluten fraction III using the standard LMI test and that performed with purified polymorphs. There is a significant correlation between the results of the two tests using both parametric and non-parametric tests $(r=0.62$, $\mathrm{t}=3.2, \quad \mathrm{p}<0.01$; Spearman's rank correlation coefficient $=0 \cdot 64, p<0 \cdot 01)$. Furthermore, the slope of the line of best fit is 0.91 with a standard deviation of the slope of $0 \cdot 28$. The slope therefore does not differ significantly from unity $(t=0.33)$ nor does the intercept differ significantly from zero (y intercept $=0 \cdot 13, \mathrm{SD}=0 \cdot 24, \mathrm{t}=0.53$ ).

These results contrast with those shown in Fig. 5 in which migration indices to purified protein derivative are shown using the standard LMI test and the test performed with the same cell types as in Fig. 3. In this case significant migration inhibition of cells from Mantoux-positive subjects is seen only in the standard test and with the combination of 
Fig. 3 Migration indices with gluten fraction III as antigen in normal controls and coeliacs using the standard LMI test and the LMI test performed with purified subpopulations of leucocytes.

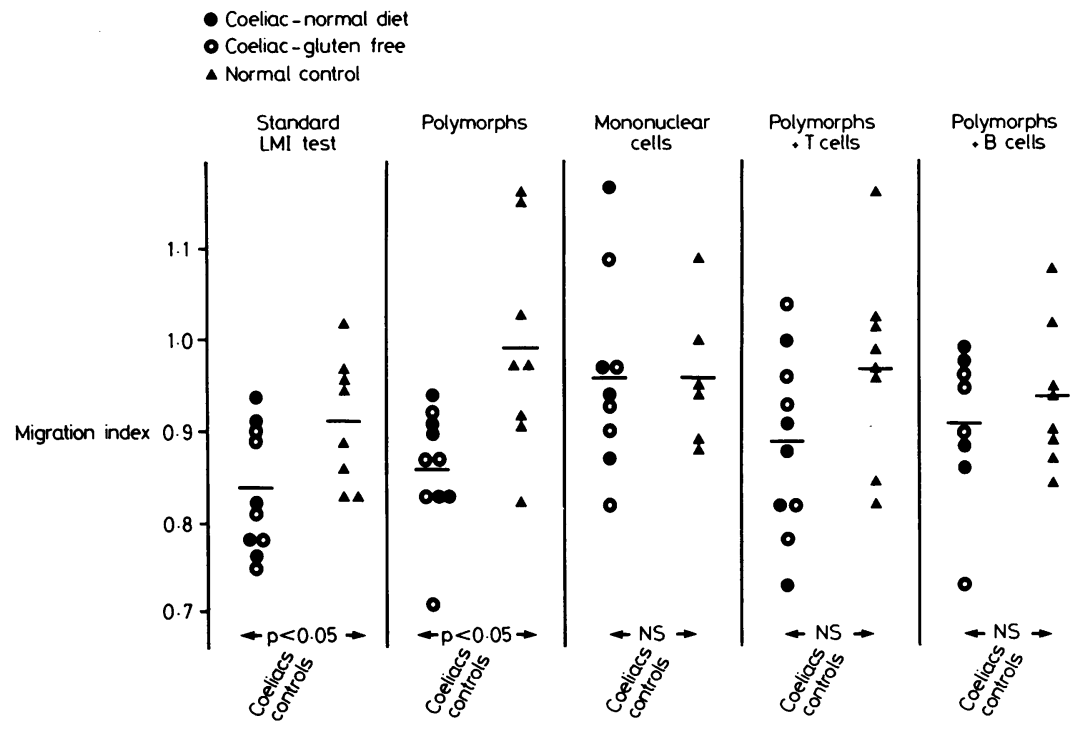

polymorphs and $\mathrm{T}$ cells. Polymorphs alone are not inhibited.

The effect of incubation of normal cells with serum from coeliac patients and of preincubation with aggregated $\mathrm{IgG}$ before incubation with coeliac serum is shown in Fig. 6. Cells from this normal

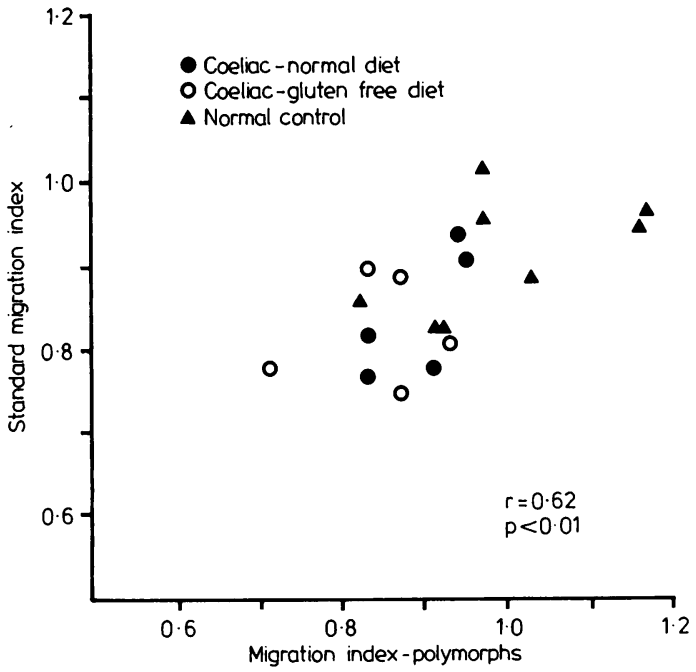

Fig. 4 Correlation between migration indices with gluten fraction III as antigen in controls and coeliacs using the standard LMI test and the LMI test performed with purified polymorphonuclear leucocytes. control subject consistently give a migration index of around 0.9 with gluten fraction III as antigen (mean of four experiments 0.91 , SD 0.02). After incubation with coeliac sera and washing, however, the cells were markedly inhibited by gluten fraction III (mean migration index 0.75 , SD 0.05 ). This sensitisation to gluten was prevented by incubation with aggregated $\operatorname{IgG}$ before the incubation with coeliac sera (mean migration index $0 \cdot 89$, SD $0 \cdot 05$ ).

\section{Discussion}

The use of the LMI test as an assay of cell mediated immunity relies on the correlation between results of the test with results of skin tests for delayed hypersensitivity. In the absence of such a correlation, as in coeliac disease, it is necessary to examine critically the mechanisms which may be producing migration inhibition.

Puromycin and other protein synthesis inhibitors have been shown in several studies to block lymphokine mediated migration inhibition. ${ }^{8} 1923$ The mechanism of action of puromycin is not understood; there is some evidence that it acts on the target cell to render it unreactive to lymphokine rather than on lymphokine release by the lymphocyte. ${ }^{18}$ The lack of effect in this study argues against the role of lympokines in the migration inhibition produced by gluten. The concentration of puromycin used is similar to that in previous studies and is shown to be sufficient by its effect on migration index to purified protein derivative in the Mantoux-positive controls. The lack of effect of 

purified protein derivative as antigen using the standard $L M I$ test and the LMI test performed with purified subpopulations of leucocytes.
Fig. 5 Migration indices with

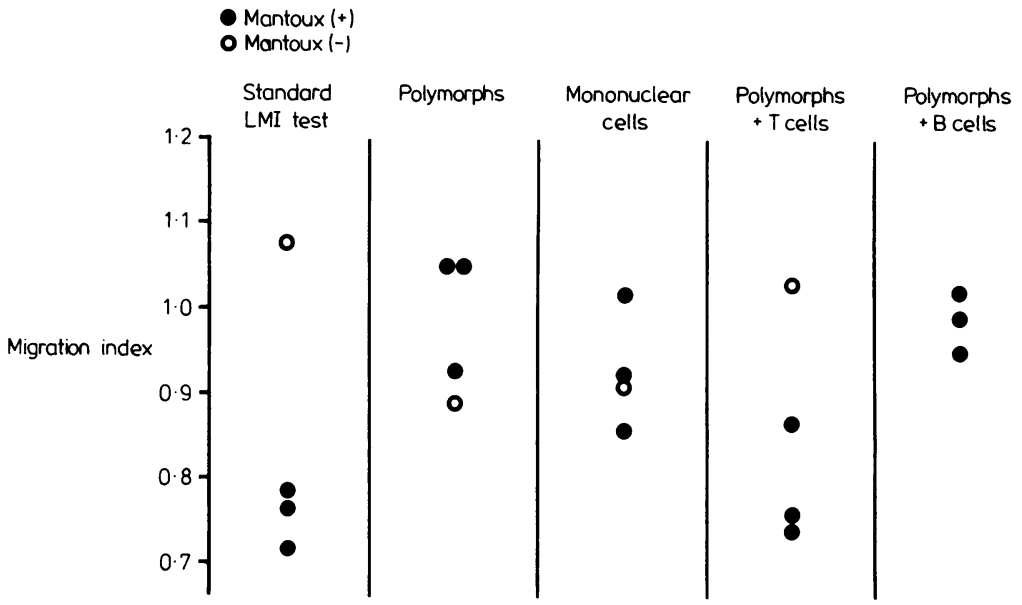

puromycin with gluten as antigen is in accord with our previous findings when jejunal biopsies from coeliac patients were cultured with gluten and continued to produce soluble inhibitors of leucocyte migration in the presence of puromycin. ${ }^{2+}$

The demonstration that purified polymorphs from

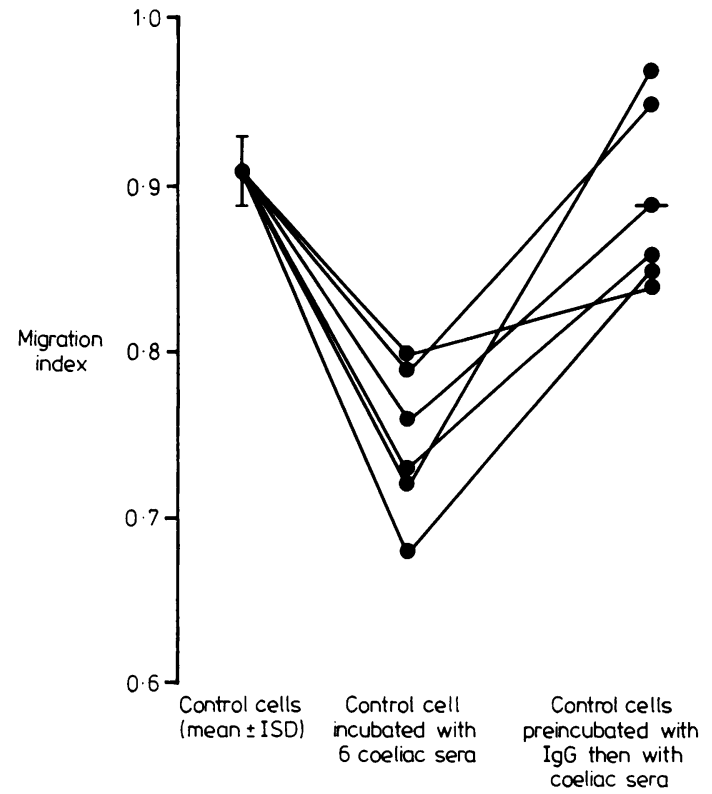

Fig. 6 Effect of incubation with coeliac sera on migration index of normal leucocytes with gluten fraction III as antigen and effect of preincubation with aggregated human $\lg G$. coeliac patients are inhibited by gluten is strong evidence against the role of lymphokine in producing migration inhibition in this system and suggests that either cytophilic antibody or direct toxicity of the antigen is involved. The latter cannot be completely excluded, although dose-response studies have shown no increased susceptibility of coeliac leucocytes to decreased viability when cultured with gluten fraction III (Simpson, unpublished observations). The addition of $T$ lymphocyte enriched cell suspensions to the polymorphs failed to increase the degree of migration inhibition, again suggesting that lymphocyte products are not contributing significantly to inhibition of migration of the polymorphs. This contrasts with the results with purified protein derivative where the polymorphs alone are unaffected but the addition of the $T$ cell preparation produces migration inhibition in the Mantoux-positive subjects.

The sensitisation of normal leucocytes to gluteninduced migration inhibition by incubation with serum from coeliac patients suggests that cytophilic antibody may be what is being measured in the LMI test as we have performed it. Inhibition of leucocyte or macrophage migration by cytophilic antibody has been shown by several groups of workers. ${ }^{11-16}$ The existence of antibodies which bind to phagocytic cells and modify their immune capabilities has been known for many years. ${ }^{25}$ Most of the experimental data concern macrophage-cytophilic antibody, ${ }^{25-27}$ though similar antibodies which bind to polymorphs and modify their antigen binding and phagocytic capabilities have been described in animals ${ }^{28} 29$ and there is some evidence that the IgG subclasses $\operatorname{IgG}_{1}$ and $\mathrm{IgG}_{3}$ in man bind to polymorphs as well as to monocytes. ${ }^{30}$ Cytophilic antibody binds to cells via 
interaction between its $F_{c}$ portion and $F_{c}$ receptors on the cell surface ${ }^{26}$ and the blocking of sensitisation of normal leucocytes with coeliac serum by preincubation with aggregated IgG supports the contention that cytophilic antibody is present in our system. It is unlikely that immune complexes are responsible for the sensitisation of the normal leucocytes, as their migration in control medium was unaffected by incubation with coeliac serum, inhibition being seen only when gluten was added.

Our results strongly suggest that the direct leucocyte migration inhibition test in coeliac disease seems to measure cytophilic antibody to gluten fractions and not lymphokine production and thus not cell-mediated immunity. The negative skin test results with gluten subfractions and variable results with lymphocyte transformation assays ${ }^{\prime}$ (which may in any case be measuring B lymphocyte transformation) together with our results means that cell-mediated immunity to gluten in coeliac disease cannot be regarded as established. It must be stressed, however, that seemingly minor differences of technique may dramatically affect the results of tests of leucocyte migration ${ }^{19}$ and it is possible that lymphokines may be detectable using different methodology. In view of our results, however, it is clear that any such experiments should include controls to exclude migration inhibition mediated by the mechanisms discussed above.

Finally, there is some evidence to suggest that antibody dependent cellular responses to gluten may be pathogenetically important in coeliac disease ${ }^{31}$ and in view of our findings further investigation of this possibility seems warranted.

We would like to thank Mr R Hall, Department of Haematology, St James's Hospital, for performing the differential white cell counts, the staff of the Department of Immunology, St James's Hospital, for performing the $\mathrm{T}$ and $\mathrm{B}$ cell counts, and Dr R B Payne for help with statistical analysis.

\section{References}

1 Asquith P, Haeney MR. Coeliac disease. In: Asquith $\mathrm{P}$, ed. Immunology of the gastrointestinal tract. Edinburgh, London, and New York: Churchill Livingstone, 1979: 66-94.

2 Douwes FR. Gluten and lymphocyte sensitisation in coeliac disease. Lancet 1976; 2: 1353.

3 Bullen AW, Losowsky MS. Cell mediated immunity to gluten fraction III in adult coeliac disease. Gut 1978; 19: $126-31$.

4 Haeney MR, Asquith P. Inhibition of leucocyte migration by alpha-gliadin in patients with gastrointestinal disease: its specificity with respect to alphagliadin and coeliac disease. In: McNicholl B. McCarthy CF, Fottrell PF, eds. Perspectives in coeliac disease. Lancaster: MTP Press, 1978: 229-42.

5 Ashkenazi P, Idar D. Handzel ZT, Ofarim M, Levin S. An in-vitro immunological assay for diagnosis of coeliac disease. Lancet 1978; 1: 627-9.

6 Rauch HC, King K. Human leukocyte migration inhibition as an indicator of cellular hypersensitivity to soluble antigens. Int Arch Allergy 1973; 44: 862-74.

7 Mitchell CG. Smith MGM, Golding PL, Eddleston ALWF, Williams R. Evaluation of the leucocyte migration inhibition test as a measure of delayed hypersensitivity in man. Clin Exp Immunol 1972; 11: 535-41.

8 Rosenberg SA, David JR. Inhibition of leukocyte migration: an evaluation of this in vitro assay of delayed hypersensitivity in man to soluble antigen. $J$ Immunol 1970; 105: 1447-52.

9 Rocklin RG, MacDermott RP. Chess L. Scholssman SF, David JR. Studies on mediator production by highly purified T and B lymphocytes. J Exp Med 1974; 140: $1303-16$

10 Tubergen DG, Feldman JD, Pollock EM, Lerner RA. Production of macrophage migration inhibition factor by continuous cell lines. J Exp Med 1972; 135: 255-66.

11 Heise ER, Han S, Weiser RS. In vitro studies on the mechanism of macrophage migration inhibition in tuberculin sensitivity. J Immunol 1968; 101: 1005-15.

12 Kostiala AAI, Kosunen TU. Delayed hypersensitivity in the guinea pig immunised with killed tubercule bacilli in adjuvant. 3. Peritoneal cell migration inhibition and macrophage cytophilic antibodies to tuberculin purified protein derivative. Acta Pathol Microbiol Scand B 1972; 80: 1-9.

13 Lockshin MD, Waxman J, Jenkins MW. Mechanism of buffy coat migration inhibition test. Experientia 1973; 29: $340-1$.

14 Amos HE. Gurner W. Olds RJ. Coombs RRA. Passive sensitisation of tissue cells. II. Ability of cytophilic antibody to render the migration of guinea-pig peritoneal exudate cells inhibitable by antigen. Int Arch Allergy 1967: 32: 496-505.

15 Wasserman DL. Immune responses to thyroglobulin in experimental allergic thyroiditis. Immunology 1965; 9: $1-10$.

16 Ortiz-Ortiz L, Zamacona G. Garmilla C, Arellano MT. Migration inhibition test in leukocytes from patients allergic to penicillin. J Immunol 1974: 113: 993-7.

17 Spitler L, Huber H. Fudenberg HH. Inhibition of capillary migration by antigen-antibody complexes. $J$ Immunol 1969: 102: 404-11.

18 Kotkes P. Pick E. Studies on the inhibition of macrophage migration induced by soluble antigenantibody complexes. Clin Exp Immunol 1975: 19: 105-20.

19 Maini RN, Roffe LM, Magrath IT, Dumonde DC. Standardisation of the leucocyte migration test. Int Arch Allergy 1973: 45: 308-21.

20 Frazer AC. Fletcher RF. Ross CAC, Shaw B. Sammons HG, Schneider R. Gluten-induced entero- 
pathy. Th: effect of partially digested gluten. Lancet 1959; 2: 252-5.

21 Boyce EA, Old LJ, Chouroulinkov I. Cytotoxic test for demonstration of mouse antibody. In: Eisen HN, ed. Methods in medical research. Chicago: Year Book Publishers, 1964: vol. 10: 39-47. Quoted by Waithe WI and Hirschorn $\mathrm{K}$ in: Weir DM, ed. Handbook of experimental immunology, 2nd ed. Oxford: Blackwell, 1973: 2: Chap 25.

22 Ling NR, Bishop S, Jeffries R. Use of antibody-coated red cell for the sensitive detection of antigen and in rosette tests for cells bearing surface immunoglobulins. J Immunol Methods 1977; 15: 279-89.

23 Gorski AJ. Superiority of corpuscular BCG to soluble PPD antigen in the leucocyte migration assay. Clin Exp Immunol 1974; 18: 149-53.

24 Howdle PD, Bullen AW, Simpson FG, Losowsky MS. Further studies in cell mediated immunity (CMI) to gluten fraction III (GF.III) in the small intestinal mucosa in coeliac disease (CD). (Abstract.) Gut 1981; 22: A421.

25 Tizard IR. Macrophage-cytophilic antibodies and the functions of macrophage-bound immunoglobulins.
Bacteriol Rev 1971: 35: 365-78.

26 Berken A. Benacerraf B. Properties of antibodies cytophilic for macrophages. J Exp Med 1966; 123: 119-44.

27 Nelson DS, Boyden SV. Macrophage cytophilic antibodies and delayed hypersensitivity. $\mathrm{Br}$ Med Bull 1967: 23: 15-20.

28 Fidalgo BV, Najjar VA. The physiological role of the lymphoid system. 3. Leucophilic globulin and the phagocytic activity of the polymorphonuclear leucocyte. Proc Natl Acad Sci USA 1967; 57: 957-64.

29 Watson DL. The effect of cytophilic $\mathrm{IgG}_{2}$ on phagocytosis by bovine polymorphonuclear leucocytes. Immunology 1976; 31: 159-65.

30 Hay FC, Torrigiani G, Roitt IM. The binding of human IgG subclasses to human monocytes. Eur J Immunol 1972; 2: 257-61.

31 Ezeoke A, Ferguson N, Fakri O, Hekkens WThJM, Hobbs JR. Antibodies in the sera of coeliac patients which can co-opt $\mathrm{K}$ cells to attack gluten-labelled targets. In: Hekkens WThJM, Pena AS, eds. Coeliac disease. Proceedings of the 2 nd International Symposium. Leiden: Stenfert-Kroese, 1974: 107-17. 